\title{
원조효과성 제고를 위한 파리선언 이행평가(phase 2) 요약*
}

\section{I. 평가의 배경, 목적 및 접근방법}

\section{1. 평가의 배경 및 목적}

\section{목 차}

I. 평가의 목적, 배경, 접근방법

II. 주요 발견사항

III. 결 론

IV. 제 언

2005년 채택된 원조효과성 제고를 위한 파리선언(이하 파리선언)은 수십 년간 지속된 원조의 질 및 영향력 향상을 위한 논의 가운데, 역사적으로 이끌어 낸 국제적인 합의이자 개혁 프로그램이다. 원조일치와 조화에 대한 여타 공동성명과 다르게, 파리선언은 2010 년까지 달성을 요하는 구체적인 목표를 통해 실용적이고 행동 지행적인 로드맵을 제시하고 있다.

이행평가의 목적은 파리선언의 적절성과 효과성, 파리선언이 원조효과성에 미친 영향, 더 나아가 파리선언이 개발성과에 미친 영향을 평가하는 것이다. 이와 같은 목적을 달성하기 위해 평가는 두 단 계로 진행되었다.

1 단계 평가는 원조효과성 제고를 목적으로, 행동변화를 평가하고 수원국 및 공여국에게 파리선언 의 약속사항을 이행하는데 더 나은 모범사례(good practice)를 제시하기 위해 수행되었다. 동 평가는

\footnotetext{
* 동 요약문은 최종 종합보고서의 'executive summary'를 번역/정리한 글이다.

Wood,B;Betts, J;Etta, F;Gayfer, J;Kabell, D;Ngwira, N;Sagasti, F;Samaranayake,M, The Evaluation of the Paris Declaration, Final Report, Copenhagen, May 2011

(http://www.ph7.dk/files/ftp/pd2011/content/pdf/PD-EN-web.pdf)
} 
2008년에 종료되어 당시 진행 중이던 원조효과성 정책논의, 즉 2008년 9월 아크라 고위급 회의에 건설적으로 기여했다.

2 단계 평가는 2007년 2011년까지 4년에 걸쳐 22개 수원국 평가, 18 개 공여국 및 다자개발기구 연구, 몇 개의 주제별 연구2)를 진행하여 원조효과성에 대한 파리선언의 기여도와 개발성과를 평가하 였다. 전지구적 차원에서 2005년 이후 원조의 효과성 제고 노력을 독립적으로 평가하였으며, 정부부 처, 입법자, 원조 관리자, 기타 특정 사용자, 그리고 원조에 관심 있는 많은 대중들을 대상으로 평가 결과를 도출하였다.

\section{2. 평가를 위한 핵심 연구 질문}

2 단계 이행평가를 통해 답을 얻고자 하는 핵심 연구 질문은 다음과 같다.

(1) 파리선언 개혁 이행과 그 영향을 야기한 요소는 무엇이며, 반면 이를 제한한 요소는 무엇인가? (파리선언의 현황)

(2) 파리선언에서 목표로 한 원조효과성에 어떤 개선사항이 있었는가? (원조효과성에 미친 영향)

(3) 원조효과성의 향상으로 지속가능한 개발성과에 미친 영향은 무엇인가? (개발성과에 미친 영향)

\section{3. 평가의 접근방법3)}

동 평가는 파리선언과 아크라 행동강령에 포함되는 약속사항, 행위자, 유인이 각자 그들의 의도를 전달했는지 여부와 전달방법을 분석하는 방식으로 진행되었다. 이를 위해, 파리선언이 작동되는 논 리를 살펴보고 개발목표에서 성과에 이르기까지 복잡한 경로를 설명했다. 이 과정에서 현재 개발 과 정에서 발견되는 또 다른 강력한 영향력과 원조의 역할에 대한 현실적인 제약점을 강조했다. 다양한 근거와 기법은 주로 정성적이지만, 가능하다면 신뢰할만한 정량적인 데이터에서 도출하기도 했다.

\section{4. 평가의 제한점}

파리선언과 같이 넓은 범주의 이니셔티브의 영향을 평가하는 데는 제약사항이 있는데, 동 평가도 몇 가지 제한점을 인정하고 있다.

(1) 비전형적인 평가대상

2) 주제별 연구는 비구속성 원조의 개발효과, 통계역량강화 지원, 취약한 상황에 대한 파리선언 적용가능성, 현재 파리선 언이 고려하지 않은 개발 형태(development source, 결론 및 제언에서 언급될 개발협력의 새로운 행위자들을 가리킴), 파리선언, 원조효과성, 개발효과성 간의 관계와 같은 다양한 주제를 다루었다.

3) 기술적인 방법론과 평가 접근방식에 대한 세부사항은 종합보고서 '첨부 5'를 참고 바란다. 
(2) 파리선언의 광범위하고 복잡한 목표 및 이와 관계된 다양한 전후 상황과 행위자

(3) 2005년 파리선언이 채택 후, 특히 개발성과를 측정하기에 한계가 있는 시간적인 제약사항

(4) 자발적인 참여로 진행된 평가와 연구

(5) 수원국 평가에 비해, 공여국 및 원조기관 성과에 대해 상세히 살펴보지 못한 점

(6) 일관적이지 않은 데이터 출처나 평가척도와 같은 기준체계

\section{II. 주요 발견사항}

\section{1. 파리선언의 현황}

\section{1) 파리선언의 적절성}

동 평가는 파리선언을 이행하는데 도움이 되기도 하고 제약이 되기도 하는 주된 정치적, 경제적, 행정적 영향력에 초점을 두어 파리선언의 적절성을 평가했다. 그 결과, 파리선언이 다양한 수원국 및 공여국/원조기관과 관련 있음이 증명되었다. 그러나 파리선언 캠페인4)의 적절성에 대한 한 가지 문 제점은, 동 캠페인이 초기에 기술적이고 형식적인 과정으로 해석되고 적용되어 변화를 꾀하는데 필 요한 정치적 및 폭넓은 사회적 참여를 저해하는 위협으로 작용했다는 것이다. 또한 급변하는 세계에 서 원조를 어떻게 정의하고 측정해야 하는지에 대해 고심해야 하는 문제도 있었다.

\section{2) 수원국 상황}

수원국이 책임을 맡은 개혁부분에 관해 2000년 2005년 이후 속도는 더디지만 발전하고 있다고 평가되었다. 수원국은 원조를 더 잘 관리하고 재정관리, 공공조달 혹은 책무성과 같은 수원국 자체의 국가적 필요를 충족시키기 위해 파리선언식5)의 개선사항을 도입했다. 또한 수원국은 정치적 변화와 다양한 위기를 견딜 정도로 변화에 대한 충분한 대응성을 가지고 있음을 발견했다.

\section{3) 공여국 상황}

수원국과 비교해보면, 공여국은 역량이 더 크고 원조개혁의 변화에 대한 부담이 크지 않다. 그러

4) 동 평가보고서의 용어정리에 따르면, 파리선언, 원조개혁 캠페인(Paris declaration, aid reform "campaign")에서 '캠페 인'은 수년에 걸쳐 파리선언의 주요하지만 어려운 목표를 달성하기 위해 전 세계의 다양한 행위자가 기울인 다양한 노 력을 가리킨다.

5) 파리선언스타일, 파리선언식 원조(Declaration-style, Decalration-type aid) 일반적으로 파리선언이 장려한 원조를 가 리킨다. 예를 들어 수원국의 우선순위 및 시스템과 일치, 수원국과 조정, 원조조화, 비구속성, 원조 예측가능성, 투명성 의 원칙을 반영한 원조를 말한다. 
나 공여국은 광범위한 국내 및 국제적 이슈 속에서, 개발원조와 원조개혁에 필요한 정치적, 행정적, 대중의 관심과 지지를 모아야 하는 어려움이 있다. 공여국이 겪는 문제점은 다음과 같다.

(1) 일관된 정책이나 체계 결여

(2) 과도하게 중앙집권적인 공여국/원조기관의 체계 및 수원국 체계와 불일치한 의사결정

(3) 기관전략과 원조효과성 의제 간 단절 및 기관차원의 유인동기 부족

(4) 기관의 위치나 본부의 위치 변화

(5) 역량한계 및 직원감소

(6) 기관의 개혁 지연 및 재정위기에서 비롯되는 예산의 압박

\section{2. 파리선언이 원조효과성6)에 미친 영향}

\section{1) 파리선언 캠페인의 효과성}

파리선언이 원조효과성 제고에 미친 영향을 살펴보기 위해서는 파리선언의 서문에 제시되었던 11 개의 목표에 달성정도를 평가7)했다. 그 결과, 파리선언 캠페인을 통해 모범사례 규범의 명확화 및 강화, 2005년 수립된 목표 달성을 위한 노력, 원조파트너십의 질 향상, 원조규모 증가 지지라는 원조 효과성에 대한 큰 진전이 있었음을 알 수 있었다.

(1) 원조관계에서 모범사레를 명확히 하고 강화하여 높은 상호기대를 정당화하고 강화함.

(2) 변화속도가 더디고 변화폭이 크지 않지만 대부분 2005년 수립된 11개 목표 달성을 위한 노력에 기여하여 더 나은 개발성과가 도출되도록 영향을 미침.

(3) 새천년개발목표의 인식제고 효과와 함께 원조규모 증가를 지지함.

(4) 투명성, 신뢰, 수원국의 주인의식 수준을 강화하여 몇몇 원조 파트너십의 질을 개선함.

6) 원조효과성 제고의 변화 척도는 원조전달의 효율성, 원조관리 및 활용, 파트너쉽 제고이다.

(1) 원조전달의 효율성

파리선언식 원조가 적용된 곳에서 관리부담이 거의 줄어들지 않았고 심지어 부담이 증가한 사례도 있었다. 그러나 수 원국 체계가 잘 정비되어 있으면 더 전략적인 지원을 감당할 수 있도록 공여국이 수원국의 역량을 강화시키기 때문 에, 파리선언식 체계가 원조에 도움을 주고 있다.

(2) 원조관리 및 활용

연구대상 국가에 대한 평가 결과에 따르면, 원조관리 및 활용에 대한 진행상황이 더디고 일관된 변화를 나타내지는 못하지만 파리선언 전 상황과 비교했을 때 파리선언식 원조가 변화에 기여한 것으로 보인다. 글로벌 프로그램은 여전 히 기타 과정과 충분히 통합되지 않았지만 몇 사례에서 개발성과가 향상된 것으로 판단된다.

(3) 개발을 위한 더 포괄적이고 효과적인 파트너십 구축

파트너십 구축에 대한 통합기준이 이슈가 되고 있으며, 파리선언이 원조관계에 대해 강조하여 수원국 및 공여국 간, 공여국들 간, 그리고 기타 이해관계자와의 파트너십에 대한 중요한 대화의 장이 열렸다. 그 결과 명백하고 실질적인 이익이 이미 조금씩 나타나고 있다.

7) 동 요약문 마지막에 첨부한 '원조효과성의 11 개 목표에 대한 종합적인 평가결과 요약'참고 


\section{2) 수원국의 변화}

수원국에게 기대했던 '역량개발'의 변화는 공여국 및 원조기관에게 기대했던 것보다도 더 어려운 것이지만, 수원국들은 원조를 관리할 뿐 아니라 국가적 필요를 충족하기 위해 변화의 길을 택했다. 역량개발은 단기간에 달성할 수 없지만, 수원국이 목표한 분야에서 역량강화를 위한 우선순위를 수 립한다면, 공여국 및 원조기관은 조정을 통해 그 우선순위를 지원하여 수원국의 체계를 강화하고 지 속가능한 역량개발을 저해하는 공여국의 관행을 줄일 수 있을 것이다.

\section{3) 공여국 및 원조기관의 변화}

몇몇 예외적인 경우를 제외하고, 공여국 및 원조기관은 체계변화를 위해 수원국에 비해 노력하지 않는 것으로 나타났다. 그 이유는 공여국 및 원조기관이 통합적이지 않고 위험 기피적이기 때문이다. 대부분 공여국은 수원국과 함께 위험을 공유하고 변화하기보다, 체계 변화의 전제조건으로 수원국에 게 높은 수준으로 순응(compliance)을 요구하고 있다. 또한 동료 압력과 공여국의 집단행동이 아직 많은 공여국 체계에 남아있어, 정부나 부처의 변경과 같이 정보가 없는 정책변화에 대해 취약한 상태 이다.

\section{3. 파리선언이 개발성과에 미친 영향}

원조개혁이 지속가능한 개발에 미친 영향에 대한 평가는 다음 4 가지 분야 즉, 1) 특정분야(특히, 수원국 평가에서 공통 연구 분야였던 보건분야) 2) 빈곤층의 필요에 대한 우선순위 3) 기관의 역량과 사회자본 강화 4) 혼합된 원조방식 개선에서 집중적으로 이루어졌다.

\section{1) 특정분야의 원조개혁}

수원국 평가 결과, 파리선언식 원조가 2005년 전에 시작되었든, 후에 시작되었든 관계없이 더 집 중적이고 효율적인 공동의 원조노력에 도움이 되었다는 명백한 증거를 밝혀냈다. 특히 특정분야 즉 보건분야에서 이 사실은 명백하게 나타났는데, 이러한 원조노력이 이미 더 나은 개발성과를 낳고 있 고 앞으로 지속적일 것이라는 전망도 할 수 있었다. 하지만, 이 분야 외에 더 넓은 범주, 예를 들면 새천년개발목표 달성과 같은 개발성과에 대해 원조개혁이 어떤 영향을 미쳤는지 근거를 충분히 찾을 수 없었다.

\section{2) 빈곤층의 필요에 대한 우선순위}

전반적으로 빈곤층, 특히 여성과 여아의 필요에 우선순위를 두는 것에는 변화가 거의 없었다. 그 
러나 2000년 2005년 이후 파리선언식 운영과 원조개혁을 통해 부가가치가 생기고 원조를 통해 몇 가지 긍정적인 변화가 있다는 근거를 발견했다. 즉, 핵심적인 전제조건은 변화에 대한 강하고 지속적 인 국가의 약속이행이며, 이것이 없다면 원조와 원조개혁은 깊이 자리 잡은 불평등에 대해서만 고심 하는 데 제한될 것이라는 점이다.

\section{3) 기관역량 및 사회자본}

수원국의 역량 부족이 큰 제약사항으로 남아있기 때문에 원조를 통해 할 일이 많이 있지만, 장기 적인 관점에서 원조와 원조개혁이 기관 역량 및 사회자본 개발 강화에 최소한 어느 정도 영향을 미쳤 다는 근거가 제시되었다.

\section{4) 혼합된 원조방식의 개선}

원조방식에 있어서 2000년 2005년 이후로 더 많은 선택사항과 혁신8)을 통해 평가 대상국 중 절 반이 개발성과에 대한 실제적이거나 잠재적인 변화를 나타냈다. 평가에 따르면, 어떤 한 가지9) 원조 방식도 자동적으로 더 나은 개발성과를 낳을 수 없고 혼합된 원조방식이 모든 수원국과 공여국에게 앞으로도 더 낫다는 의견을 제시했다.

\section{III. 결 론}

파리선언의 5 대 원칙과 56 개 약속사항은 거의 모두 원조의 질 및 필요한 파트너십의 향상과 관련 이 있다고 증명되었다. 파리선언이 이행된 방식은 적절성을 저해한 면도 있었으나, 중단되지 않고 상 당한 변화와 격동을 이겨냈다.

20년 25년 전 원조상황과 비교해볼 때, 현재 원조 관행은 더 투명해지고 공여국 주도의 원조도 감소했다. 과거에 분절적으로 개발되고 시험되었던 개혁을 위한 약속사항과 수단이 파리선언 캠페인 을 통해 전파되었다. 파리선언으로 인해 급변하리라는 비현실적인 기대를 갖기도 했지만 더 나은 파 트너십과 원조 관행을 위한 합의된 규범과 기준이 강화되었다.

전체적인 평가 결과는 5 대 원칙 중에 수원국의 수원의식이 가장 많이 향상되었고, 원조 일치와 조 화와 관련해서는 변화가 일관되지 않게 나타나고 있으며, 개발성과 관리와 상호 책무성은 가장 발전 이 더딘 것으로 나타났다. 결론적으로 파리선언으로 아직 원조관리의 부담을 바라는 대로 줄이지는 못하고 있다는 것이다. 그러나 파리선언식 원조를 도입하면서 늘어난 관리부담이 파리선언으로 인한

8) 특히 분야수준에서 공여국 공동원조가 더 많았다.

9) 예를 들어 예산지원, 분야지원, 프로그램 또는 프로젝트 등 
이익 즉, 원조의 질 및 투명성 개선, 효과적인 파트너쉽, 그리고 원조 규모 확대 지지의 이익을 상쇄 시키지는 않는다.

더불어 파리선언이 미치지 않는 범위에 해당되는 개발협력의 형태와 원조의 흐름10)에 대한 투명성 이 결여되었고 그들에 대한 신뢰할 만한 데이터가 없다는 심각한 문제를 발견했다. 이 범위에 속하는 행위자들은 $\mathrm{OECD} / \mathrm{DAC}$ 공여국의 $1 / 4$ 의 규모로 원조에 참여하고 있으므로, 파리선언과 아크라 행동 계획에서 언급한 투명성, 원조효과성 기준, 상호책무성이 적용되어야 한다. 또한 파리선언과 아크라 행동계획이 이들을 포함하도록 하여 수원국의 개혁으로 얻은 이익이 감소되지 않도록 해야 한다.

\section{N. 제 언}

\section{1. 기타 행위자에 대한 파리선언의 적절성}

동 평가의 중심은 2000년 2005년 이후 수원국 및 공여국이 파리선언 범위 내에서 수행한 원조개 혁 행동이지만 수원국 평가 및 기타 연구 결과, 아크라 행동계획에서 기타 행위자와 개발협력 형태가 개발과 원조에서 중요한 역할을 하고 있고 그 규모도 증가한다는 사실을 확인했음을 발견했다. 또한 이들 중 몇몇은 원조효과성 노력에 함께 동참하고 있고 시민사회의 경우, 부산세계개발원조총회에서 이에 대한 보고를 하기로 되어 있다.

그때까지 동 평가가 이 행위자들에게 제언을 제시하는 것은 권한 밖의 일이지만, 여기에서 제시되 는 제언이 모든 기타 행위자와도 관련이 있다는 근거를 강조하는 것은 중요하다.

\section{2. 수원국 및 공여국/원조기관의 정책입안자에 대한 제언}

\section{1) 냉철한 정치적 선택을 하고 수행해야 한다.}

평가 결과, 수원국 및 공여기관의 성공적인 개혁의 핵심은 고위급의 정치적 개입과 지지라는 것을 발견했다. 따라서 한국에서 개최되는 부산세계개발원조총회에서는 난제에 대한 경험과 해결, 미래 방향 수립을 위한 고위급의 정치적 개입을 재추진하고 유지하기 위한 혁신적인 방안을 모색해야 한 다. 이를 위해 의제는 형식적이지 않아야 하고, 정치적 선택에 초점을 맞추어 경험이 풍부하고 새로 운 리더들, 심지어 아직 파리선언에 참여하지 않은 국가와 기관의 리더까지도 흥미를 갖고 참여하도 록 유도해야 한다. 또한 개혁 중에 지속적으로 개최될 포럼에서도 강력한 정치적 개입이 이뤄지도록

10) IV.제언에서 언급될 국내 및 국제 시민사회기관, 파리선언이 채택하지 않은 양허성 재정(정부, 글로벌프로그램, 민간부문 행위자들), 지역적, 남남, 삼각 등 기타 개발협력 참여자들, 양허성 자원이전을 포함하거나 하지 않은 투자를 가리킴. 
혁신적인 방법을 고안해 내야 한다.

\section{2) 투명성, 상호책무성, 공동 위험관리에 집중해야 한다.}

가장 변화가 필요한 부분은 (1)수원국 주인의식, 원조일치 및 조화, 투명성 및 상호책무성의 원칙 준수 (2)공동 위험관리 원칙 추가 (3)수원국 주도의 공동행동에 대한 집중이다. 평가에서 투명성은 효 과성과 상호책무성의 필수불가결한 기초 요소로서 반복적으로 언급되었던 부분이고, 공동 위험관리 는 처리원칙으로써 개발 및 수원국에 대한 위험과 불확실성을 공개적으로 인정하고 파트너십을 통해 공동으로 대응하자는 상호 약속사항이라는 의미를 갖는다. 즉, 개발성과 관리는 분리된 원칙이라기 보다 지원기술로써 고려되어야 한다.

\section{3) 수원국의 원조효과성 노력에 집중하고 이를 강화해야 한다.}

앞으로 원조효과성 노력의 리더십은 수원국 중심의 체계를 강화하고 독립성을 갖춰서 개별 수원국 수준에서 고려되고 지원되어야 한다. 국제적인 수준에서는 원조효과성의 기준수립, 분석, 보고, 모니 터링하는 상부구조가 있다면 부담을 덜고 더 직접적으로 도움이 될 것이다.

평가의 주된 발견사항은 원조개혁의 주요원칙과 파리선언의 이행사항이 모든 국제원조의 형태에 적용 가능하지만, 개별 수원국의 상황에 따라 개혁에 대한 가중치, 우선순위, 기간에 대한 적용이 달 라진다는 것이다. 수원국 수준에서 파트너십에 가중치를 둔다면 국제적인 수준에서는 부담이 되는 프로그램을 줄이고 중요한 업무 몇 개에 집중하도록 해야 한다.

또한 수원국 차원의 연례포럼이 핵심체계11)가 되도록 강화해야 한다. 이를 위해서 원조파트너십을 관리하고 모니터링하려는 강력한 제도가 뒷받침되어야 하며 수원국 차원에서 개혁과 수행에 대한 주 요 정량적인 목표와 시간을 선택하여 수립하고 합의해야 한다. 그 다음, 수원국과 모든 공여국 간 장 기적인 원조합의에 대한 논의가 진행되어야 원조 조정과 예측성을 개선할 수 있게 된다.

상호책무성에 대한 문제를 해결하기 위해서는 모든 수원국이 독립적인 조력자/조사위원을 두어 이 러한 과정을 모니터하고 추진하도록 해야 한다. 이들은 수원국 참여자와 공여국 커뮤니티와 일하면 서 모범사례의 규범을 만들고 상호책무성을 강화하기 위해 연례포럼과 국제 보고 체계에 독립적으로 정보를 제공할 수 있을 것이다.

\section{4) 원조개혁의 이점이 모든 개발협력 형태에 확대되도록 해야 한다.}

모든 개발협력 형태에는 취약국에 대한 협력 및 인도주의적 협력, 기후변화, 양허성 개발협력 참 여자, 시민사회, 지역적, 남남, 삼각협력도 포함된다. 모든 개발협력이 다 원조의 요소를 가지고 있

11) 연례포럼이 정보공유, 상호 성과검토, 광범위한 참여와 자문, 우선순위 및 목표, 원조 일치 및 조화에 대한 내용을 다 루는 핵심체계가 되도록 강화해야 한다. 
지는 않기 때문에 필요한 부분은 개선할 필요가 있겠다. 그러나 파리선언의 56 개 이행사항이 기초 규범 및 행동강령으로써 실질적으로 양허성의 여부에 관계없이 모든 국제원조 형태에 유효하다고 증 명되었다는 점을 고려할 때, 규범이 너무 과도하게 확대된다거나 원조의 범위를 넘어서기까지 그 의 미가 희석되어서는 안 된다.

\section{5) 다음 개혁단계에서 향상된 국제적 파트너십이 강화되도록 해야 한다.}

파리선언 개혁 캠페인을 위해 수원국과 공여국 간 특별히 구축된 공동 파트너십을 통해 발전하는 것이 중요하다. 이를 위해 국제적인 절차와 책임사항도 만들어야 한다. 원조효과성을 위한 국제적인 신규 절차 관련, 핵심은 국제적 및 수원국 수준에서 모든 재정과 활동 관련 투명성에 대한 확실한 기 반을 다지는 것이다.

\section{3. 수원국 정책입안자에 대한 제언}

6) 자국의 원조개혁 진전을 위해 최고의 리더십과 책임성을 갖춰야 한다.

수원국은 원조효과성 개선을 위해 최고의 리더십과 책임성을 갖추어야 하는데, 이는 고위급 정치 의 지속적인 개입 및 공여국과 조정하고 참여를 유도할 수 있는 내부 체계 강화에 기반을 두어야 한 다. 특히, 내부체계는 독립적인 조력자/조사위원을 통해 상호 책무성 및 모니터링을 지원하도록 하 여 강화할 수 있다. 수원국과 공여국의 관계는 한 수원국이 상대하는 공여국이 다수라는 불균형적이 고 복잡한 관계이기 때문에 핵심단계에서 이 관계를 돕는 제 3 자의 역할이 필요하기도 하다. 따라서 모든 수원국에게 원조 관리와 개혁 과정을 모니터하고 돕는 독립적인 협력자나 조사위원을 두도록 제언한다.

\section{7) 역량강화를 위한 전략과 우선순위를 수립해야 한다.}

수원국은 자국의 공공정책과 운영을 위한 역량강화에 대해 실행가능한 전략을 수립해야 한다. 이 과정을 통해 수원국이 분명한 우선순위를 제시하게 되므로 공여국은 목적에 맞는 지원을 할 수 있게 된다. 평가를 통해 가시적인 해결방법을 찾지는 못했으나, 역량강화를 지원하기 위해 핵심 우선순위 사항을 수립하는 것이 필요하다는 결과를 도출했다. 이는 공여국이 약속한 사항인 원조일치와 원조 규모 증가를 사수하는 선제조건이기도 하다.

\section{8) 빈곤, 소외 및 부패를 퇴치하기 위해 정치적 우선순위와 명확한 행동강령을 강화해야 한다.}

많은 수원국 정부는 가장 고질적인 개발 문제인 빈곤, 소외 및 부패를 해결하기 위해 정치적인 우 선순위와 집중된 행동에 신경 써야 한다. 평가결과, 가장 좋은 원조와 원조개혁도 강력하고 효과적인 
국가의 약속과 행동을 장려하고 강화할 뿐 이를 대체할 수 없음이 밝혀졌다.

반면, 부패에 대한 정보가 대중에게 조금씩 알려지면서 이에 대한 분노도 증가하고 있다. 그 결과, 원조효과성 개선에 대한 가장 좋은 의도와 목표가 좌절되고 더 나은 파트너십의 잠재성이 제한되었 다. 이 이슈를 해결한다면 투명성제고, 원조관리에 대한 수원국 중심의 대화, 상호책무성 및 위험관 리에 대한 개방적인 접근방식에 대한 노력이 2 배가 되어 이익을 얻을 수 있을 것이다.

\section{4. 공여국 정책입안자에 대한 제언}

\section{9) 원조 및 원조개혁의 전지구적인 이해관계를 원조 전달과 일치시켜야 한다.}

공여국과 원조기관은 원조프로그램 및 역사적인 협정의 중대한 이해관계와 더디고 일관되지 못한 개혁 결과의 격차를 고위급 정치 수준에서 인정하고 바로잡아야 한다. 즉, 중대한 지역적 정치적 이 해관계와 정치적 이행약속을 공유하여 모든 공여국이 원조개혁을 저해하는 내부의 제도적 혹은 행정 적 장애물을 극복하는 방법을 마련하는 것이 시급하다. 정치적 결단을 내리면, 정부 예산, 회계, 직 원 채용조건과 같은 제약조건도 효과적인 개발협력을 위한 조건에 맞도록 조정할 수 있다.

\section{0) 위험에 직면하고 이를 관리하며, 실패는 인정해야 한다.}

공여국은 개발 및 개발원조가 내재적으로 불확실하고 위험하다는 것을 솔직히 인정하고 수원국과 성숙한 파트너십을 통해 공동으로 위험을 관리할 방법을 마련해야 한다. 개발과 원조에 대한 불확실 성과 위험, 대응방법 및 학습내용에 대해 대중에게 현실적으로 이해시키는 방법을 사용해야 한다. 예 를 들면 평가와 같은 최신의 이니셔티브와 효과적인 수단이 여기에 포함된다. 동 평가에서도 개발협 력의 새로운 접근방법이 실제로 전통적인 프로젝트처럼 위험하지 않다는 증거를 찾았고, 개발이익을 강화하는 한편 위험을 안전하게 관리하는 새로운 모델이 있음을 발견했다.

\section{1) 균형잡힌 공여국의 노력을 위해 무임승차에 대한 동료 압력을 강화해야 한다.}

공여국과 원조기관은 고위급 정치수준에서 파리선언에서 기대했던 건설적인 동료 압력이라는 수 단을 활용해야 한다. 평가결과, 수원국은 자신의 우선순위를 정의하고 여러 공여국 원조와 일치 및 조화시키도록 노력하며 원조에 대한 정보를 수집 및 발간하고 수원국 차원에서 상호책무성을 위한 조건을 강화하는데 주도적 역할을 할 수 있다고 했다. 몇몇 공여국은 이 방식을 따르고 있고 이 절차 를 지지하고 있다. 그러나 여타 공여국은 지금까지 의지가 없거나 이를 실천할 수 없어서 파리선언에 서 합의된 비전을 달성할 수 없는 매우 불균일한 성과를 낳았다. 따라서 고위급회담을 통해 공여국이 건설적인 동료압력을 활용하여 원조개혁의 다음 단계에 대한 균형 잡히고 일관된 대응을 할 수 있도 록 하는 것이 중요하다. 
원조효과성의 11 개 목표에 대한 종합적인 평가결과 요약

\begin{tabular}{|c|c|c|c|c|c|c|}
\hline Intended outcome ${ }^{56}$ & $\begin{array}{l}\text { Main } \\
\text { initiative/re- } \\
\text { sponsibility }\end{array}$ & $\begin{array}{l}\text { Degree of } \\
\text { difficulty }\end{array}$ & $\begin{array}{l}\text { Starting } \\
\text { points in } \\
2000-05^{58}\end{array}$ & $\begin{array}{l}\text { Pace and } \\
\text { extent of } \\
\text { change }\end{array}$ & $\begin{array}{l}\text { Distance } \\
\text { remaining }\end{array}$ & $\begin{array}{l}\text { Strength of } \\
\text { evidence }^{61}\end{array}$ \\
\hline \multicolumn{7}{|c|}{ Country ownership of development } \\
\hline $\begin{array}{l}\text { I. Stronger national develop- } \\
\text { ment strategies and operational } \\
\text { frameworks: } \\
\text { i. National strategic }\end{array}$ & \multirow[t]{2}{*}{$\begin{array}{l}\text { Partner } \\
\text { countries }\end{array}$} & i. Moderate & $\begin{array}{l}\text { i. Mostly } \\
\text { midstream }\end{array}$ & $\begin{array}{l}\text { i. Moderate to } \\
\text { fast }\end{array}$ & i. Little & \multirow[t]{2}{*}{ Good } \\
\hline ii. Detailed operational & & ii. High & ii. Mostly low & $\begin{array}{l}\text { ii. Mostly } \\
\text { slow/some } \\
\text { moderate to } \\
\text { fast }\end{array}$ & $\begin{array}{l}\text { ii. Substantial } \\
\text { to some }\end{array}$ & \\
\hline $\begin{array}{l}\text { II. Increased alignment of aid } \\
\text { with partner country: } \\
\text { i. Priorities, systems and } \\
\text { procedures }\end{array}$ & \multirow[t]{2}{*}{$\begin{array}{l}\text { Donors / } \\
\text { Agencies }\end{array}$} & i. Moderate & \multirow[t]{2}{*}{ Mostly low } & i. Mostly slow & \multirow[t]{2}{*}{$\begin{array}{l}\text { Substantial on } \\
\text { both }\end{array}$} & i. Adequate \\
\hline $\begin{array}{l}\text { ii. Building of capacity in } \\
\text { systems }\end{array}$ & & ii. Limited & & ii. Mostly slow & & ii. Good \\
\hline $\begin{array}{l}\text { III. Defined measures and } \\
\text { standards of performance } \\
\text { and accountability in country } \\
\text { systems }\end{array}$ & $\begin{array}{l}\text { Partner } \\
\text { countries }\end{array}$ & High & $\begin{array}{l}\text { Mostly low/ } \\
\text { some mid- } \\
\text { stream }\end{array}$ & $\begin{array}{l}\text { Mostly slow/ } \\
\text { some moder- } \\
\text { ate to fast }\end{array}$ & $\begin{array}{l}\text { Substantial to } \\
\text { some }\end{array}$ & Good \\
\hline \multicolumn{7}{|c|}{ Building more inclusive and effective partnerships for development } \\
\hline $\begin{array}{l}\text { IV. Less duplication of efforts } \\
\text { and rationalised more cost- } \\
\text { effective donor activities }\end{array}$ & $\begin{array}{l}\text { Donors / } \\
\text { Agencies }\end{array}$ & $\begin{array}{l}\text { Limited to } \\
\text { moderate }\end{array}$ & Mostly low & $\begin{array}{l}\text { Mostly slow/ } \\
\text { some moder- } \\
\text { ate to fast }\end{array}$ & $\begin{array}{l}\text { Substantial to } \\
\text { some }\end{array}$ & Good \\
\hline $\begin{array}{l}\text { V. Reformed and simplified } \\
\text { donor policies and procedures, } \\
\text { more collaborative behaviour }\end{array}$ & $\begin{array}{l}\text { Donors / } \\
\text { Agencies }\end{array}$ & Limited & Mostly low & $\begin{array}{l}\text { Mostly slow/ } \\
\text { some moder- } \\
\text { ate to fast }\end{array}$ & $\begin{array}{l}\text { Substantial to } \\
\text { little }\end{array}$ & Good \\
\hline
\end{tabular}

56 Summarised.

57 Scale: High, Moderate, Limited, Straightforward.

58 Scale: Uniformly high, mostly midstream, mostly low, uniformly low.

59 Scale: Fast, moderate, slow, very slow, none or regression.

60 Scale: Substantial, some, little, none.

61 Scale: Very good, good, adequate, poor (takes account of supplementary sources available). 


\begin{tabular}{|c|c|c|c|c|c|c|}
\hline Intended outcome $\mathrm{S}^{56}$ & $\begin{array}{l}\text { Main } \\
\text { initiative/re- } \\
\text { sponsibility }\end{array}$ & $\begin{array}{l}\text { Degree of } \\
\text { difficulty }\end{array}$ & $\begin{array}{l}\text { Starting } \\
\text { points in } \\
2000-05^{58}\end{array}$ & $\begin{array}{l}\text { Pace and } \\
\text { extent of } \\
\text { change }\end{array}$ & $\begin{array}{l}\text { Distance } \\
\text { remaining }\end{array}$ & $\begin{array}{l}\text { Strength of } \\
\text { evidence }^{61}\end{array}$ \\
\hline $\begin{array}{l}\text { Vla. More predictable and } \\
\text { multi-year commitments on } \\
\text { aid flows }\end{array}$ & \multirow[t]{2}{*}{$\begin{array}{l}\text { Donors / } \\
\text { Agencies }\end{array}$} & $\begin{array}{l}\text { i. Moderate } \\
\text { to high for } \\
\text { bilaterals, } \\
\text { limited for } \\
\text { multilaterals }\end{array}$ & i. Mostly low & i. Mostly slow & $\begin{array}{l}\text { i. Substantial } \\
\text { to some }\end{array}$ & i. Good \\
\hline $\begin{array}{l}\text { Vlb. More shared conditionalities } \\
\text { (Accra commitment, para. 25) }\end{array}$ & & ii. High & ii. Mostly low & ii. Mostly slow & ii. Substantial & ii. Poor \\
\hline $\begin{array}{l}\text { VII. Sufficient delegation of } \\
\text { authority and incentives to } \\
\text { donors' field staff for effective } \\
\text { partnership working }\end{array}$ & $\begin{array}{l}\text { Donors / } \\
\text { Agencies }\end{array}$ & $\begin{array}{l}\text { Limited to } \\
\text { moderate }\end{array}$ & $\begin{array}{l}\text { Mostly low/ } \\
\text { some mid- } \\
\text { stream }\end{array}$ & $\begin{array}{l}\text { Mostly slow/ } \\
\text { some moder- } \\
\text { ate to fast }\end{array}$ & $\begin{array}{l}\text { Substantial to } \\
\text { little }\end{array}$ & Good \\
\hline $\begin{array}{l}\text { VIII. Sufficient integration } \\
\text { of global programmes and } \\
\text { initiatives into partner countries } \\
\text { broader development agendas }\end{array}$ & $\begin{array}{l}\text { Global } \\
\text { programmes } \\
\text { and their sup- } \\
\text { porters }\end{array}$ & Moderate & Uniformly low & $\begin{array}{l}\text { Mostly slow/ } \\
\text { some moder- } \\
\text { ate }\end{array}$ & $\begin{array}{l}\text { Substantial to } \\
\text { some }\end{array}$ & Adequate \\
\hline $\begin{array}{l}\text { IX. Stronger partner countries } \\
\text { institutional capacities to plan, } \\
\text { manage and implement results- } \\
\text { driven national strategies }\end{array}$ & $\begin{array}{l}\text { Partner } \\
\text { countries }\end{array}$ & High & Mostly low & $\begin{array}{l}\text { Mostly slow/ } \\
\text { some moder- } \\
\text { ate }\end{array}$ & $\begin{array}{l}\text { Substantial to } \\
\text { little }\end{array}$ & Adequate \\
\hline \multicolumn{7}{|c|}{ Delivering and accounting for development results } \\
\hline \multirow{2}{*}{$\begin{array}{l}\text { Xa. Enhanced donors and } \\
\text { partner countries' respective } \\
\text { accountability to their citizens } \\
\text { and parliaments }\end{array}$} & $\begin{array}{l}\text { Donors/ } \\
\text { Agencies }\end{array}$ & $\begin{array}{l}\text { Straightfor- } \\
\text { ward }\end{array}$ & $\begin{array}{l}\text { Mostly mid- } \\
\text { stream }\end{array}$ & $\begin{array}{l}\text { Mostly slow/ } \\
\text { some moder- } \\
\text { ate to fast }\end{array}$ & Some to little & Good \\
\hline & $\begin{array}{l}\text { Partner } \\
\text { countries }\end{array}$ & Limited & Mostly low & $\begin{array}{l}\text { Mostly slow/ } \\
\text { some moder- } \\
\text { ate }\end{array}$ & $\begin{array}{l}\text { Substantial to } \\
\text { little }\end{array}$ & Adequate \\
\hline \multirow{4}{*}{$\begin{array}{l}\text { Xb. } \\
\text { i. Enhanced transparency for } \\
\text { development results } \\
\text { ii. Structured arrangements for } \\
\text { mutual accountability }\end{array}$} & \multirow[t]{2}{*}{$\begin{array}{l}\text { Donors / } \\
\text { Agencies }\end{array}$} & $\begin{array}{l}\text { i. Straightfor- } \\
\text { ward }\end{array}$ & \multirow{2}{*}{$\begin{array}{l}\text { Mostly } \\
\text { midstream on } \\
\text { both }\end{array}$} & $\begin{array}{l}\text { i. Mostly slow } \\
\text { to moderate }\end{array}$ & $\begin{array}{l}\text { i. Little to } \\
\text { some }\end{array}$ & \multirow[t]{4}{*}{$\begin{array}{l}\text { i. Good } \\
\text { ii. Adequate }\end{array}$} \\
\hline & & ii. High & & $\begin{array}{l}\text { ii. Slow to } \\
\text { none }\end{array}$ & ii. Substantial & \\
\hline & \multirow[t]{2}{*}{$\begin{array}{l}\text { Partner } \\
\text { countries }\end{array}$} & i. Moderate & \multirow[t]{2}{*}{$\begin{array}{l}\text { Mostly low on } \\
\text { both }\end{array}$} & $\begin{array}{l}\text { i. Mostly slow } \\
\text { to moderate }\end{array}$ & $\begin{array}{l}\text { i. Little to } \\
\text { substantial }\end{array}$ & \\
\hline & & $\begin{array}{l}\text { ii. Moderate to } \\
\text { high }\end{array}$ & & $\begin{array}{l}\text { ii. Slow to } \\
\text { none }\end{array}$ & ii. Substantial & \\
\hline \multirow{2}{*}{$\begin{array}{l}\text { XI. Less corruption and more } \\
\text { transparency; strengthening } \\
\text { public support and effective } \\
\text { resource mobilisation and } \\
\text { allocation }\end{array}$} & $\begin{array}{l}\text { Donors / } \\
\text { Agencies }\end{array}$ & Limited & $\begin{array}{l}\text { Mostly mid- } \\
\text { stream }\end{array}$ & $\begin{array}{l}\text { Mostly mod- } \\
\text { erate }\end{array}$ & Some & Adequate \\
\hline & $\begin{array}{l}\text { Partner } \\
\text { countries }\end{array}$ & High & $\begin{array}{l}\text { Mostly low, } \\
\text { some mid- } \\
\text { stream }\end{array}$ & Mostly slow & Substantial & Poor \\
\hline
\end{tabular}

